\title{
Assisted reproductive technological blunders (ARTBs)
}

\author{
John Harris
}

When things go wrong with assisted reproduction we should look at what's best for everyone in the particular circumstances

A RTBs, as we must now call them, are becoming more and more frequent. In the recent United Kingdom case (discussed in April $J M E^{1-3}$ ) Mr and Mrs A, a "white" couple, gave birth to twins described as "black". The mix up apparently occurred because a Mr and Mrs B, a "black" couple, were being treated in the same clinic and Mrs A's eggs were fertilised with $\mathrm{Mr}$ B's sperm. Mr and Mrs A love the twins and wish to keep them and the facts seem to be that Mrs A is the genetic mother of the twins but her partner is not the genetic father. Under English law, in assisted reproduction, the woman who gives birth to the child is the legal mother and this is true also in cases of surrogacy. I think there is no doubt in this case that English law has taken the right path and that it would be unconscionable to contemplate taking a child away from the woman who had undergone the risks and pains of pregnancy and childbirth and the bonding process that goes along with that when she wishes to keep the child particularly when there is no substantial and pressing evidence that she would be an unsafe parent. I argued this in my book The Value of Life ${ }^{4}$ and I think it is still true. So in this case justice, morality, and decency are served by confirming $\mathrm{Mr}$ and Mrs A as the parents of the children. Since in English law there is some ambiguity over paternity and how that is to be assigned and since $\mathrm{Mr} \mathrm{A}$ is apparently not the genetic father, I think it is important that $\mathrm{Mr} \mathrm{B}$ or whoever does turn out to be the sperm donor in this case is protected from the responsibilities of paternity (financial maintenance etc) and also is not permitted the right to access or contact which might otherwise be thought to go with genetic paternity.

\section{GENETIC ORIGINS}

This raises very interesting and complex questions about genetic origins, genetic identity, and the desirability or undesirability of full knowledge disclosure and access to all the types of relatedness that can exist between human beings. In their very interesting contribution to this debate Murray and Kaebnick made two interesting but somewhat perplexing assertions. ${ }^{3}$ They claim: "The child born to a woman who is also its genetic mother is her biological child in both senses. The man supplying the sperm is the biological father. So much is beyond dispute." This, if accurate, is of course a tautology. But is it accurate in the senses implied and is it beyond dispute? A genetic mother may be the mother of the mitochondrial DNA but possibly not the 23 chromosomes, or vice versa. Moreover, the relatively recent technique of "haploidisation" allows us to take an adult cell, divide its genetic material in half, use the 23 chromosomes from one half to act as a "sperm" to fertilise an egg and combine with the 23 chromosomes in the egg.

In theory a woman could use haploidisation to clone herself. There would, however, be a high risk of two identical chromosomes resulting and therefore a high risk of any "bad" genes appearing in a double dose and causing abnormalities. This technique combined with successful preimplantation genetic diagnosis (PIGD) might, however, eliminate such a risk. The only certainly "safe" embryos produced in this way would be clones of the mother/sister. Or, the "genetic mother" may be a cell nuclear donor who uses a host egg with the mitochondrial DNA of another woman. Either the 23 or the 46 chromosomes or the mitochondrial DNA are "genetic motherhood". Equally, the child, if it is a clone, may have the sperm donation removed many generations. Whether the cell nucleus donor (if that is a man) or the original sperm provider is the biological father is not beyond dispute because the meaning of "biological father" is not beyond dispute. It used to be said, "motherhood is a fact, paternity merely a hypothesis". Alas, the days when this joke had even a ring of truth are long gone!

Murray and Kaebnick also analysed the problem in terms of different "meanings of parenthood" and identified parenthood as biology, parenthood as intention, and parenthood as childrearing. I have to say I fail to understand their second category "parenthood as intention". Since I may intend to be a parent but never become one, it seems rather odd to think that my intention to become one somehow makes me a type of a parent in the absence of some resulting progeny. On this view, parenthood as intention is rather like being a millionaire in intention but not in money! Moreover, because parenthood as intention can be an empty category of parenthood and because it is very likely that a majority of children worldwide are conceived without any intention on the part of those who do the conceiving to become parents, it seems that parenthood as intention is hardly a category or type or even a plausible "meaning" of parenting. I also do not see much future in asking, or indeed trying to answer, the question as to who are the real parents? If such a question is insisted on, however, it seems to me that the only answer to that question is that the real parents of a child are the parents who love, care for, and rear that child whether or not they intended to become its parents, and whether or not they are genetically related to the child.

\section{GENETIC RELATEDNESS}

It is sometimes said that genetic relatedness between adults and children or for that matter between adults and adults somehow confers a priority in relationships and that in particular it is in a child's interests that its genetic origins are known and also that it is in the adult's interests or indeed is somehow their entitlement to know their genetic relatedness to their children. All of this seems to be doubtful. It has been argued, for example, that uncertainty about one's genetic origins can cause psychological problems and expose a child to dangers. ${ }^{5}$ There are two main reasons why one might wish to know one's genetic origins. One is curiosity about personalities, about who the individuals are or were whose genes I share; what their stories were, how I came to be conceived, and so on. The second is concern about genetic traits that I may have inherited and the desirability of my being aware of any genetic dangers or opportunities that my particular constitution may confer on me. These two stories have now come apart because whereas formerly, genetic histories, family histories, were the only source of genetic warnings, the completion of the human genome project and consequently the imminence of complete genetic profiling means there is another source of this information, quite independent of family histories. So that very soon, if the desirability of knowing genetic origins is supposedly "health related", I may acquire this information 
quite independently of knowledge about the personalities involved in my genetic origins. Whether or not curiosity about the personalities involved is of a sort that requires satisfaction, given the complexities of satisfying that curiosity, is a very large question with many alarming possible consequences.

Other things being equal of course it is nice to attach personal stories to one's origins; but consider that if we are to grant any entitlement to that sort of genetic information, that is to say not simply information about genes but information about personalities and identities, a whole range of consequences may follow. It is believed that there is a very high so called "nonpaternity" rate. That is, many husbands and partners are not the genetic fathers of the children they believe to be "theirs" in the genetic sense. It is unclear how widespread this phenomenon is but estimates vary between $0.5 \%$ and upwards of $30 \%$ in some communities. ${ }^{6}$ The recognition of an entitlement to information about the personalities involved in one's genetic origins would threaten the peace and harmony of very many families to no obvious purpose. If we grant this right in the case of assisted reproduction or in the case of egg or embryo donation, adoption etc it seems inconsistent not to grant it to every child and for that matter to every father (or mother now that egg donation and surrogacy are more common). It is unclear to me that by making this a comprehensive right or entitlement we would be creating a better world. Indeed, we might be better advised to minimise the importance of knowledge of the personalities that go along with genes and simply highlight the health related importance which can be or will soon be able to be derived from genetic testing alone, quite independently of family histories.

There is another reason for downplaying the personality element of genetic relatedness. We now know that a mother shares $99.95 \%$ of her genes with her daughter. Indeed, you and I (I believe we have never met but who knows who our fathers (or mothers) were or who our children may be?), as two randomly selected persons on the planet, share $99.90 \%$ of our genes with one another. We are very closely genetically related, separated by $0.5 \%$ in the number of our genes. (I shall soon be looking to you for maintenance!) In view of these facts I confess that I have also come to have greater affection for bananas, with which I share around $50 \%$ of my genes, than was formally the case. This is altogether healthy and perhaps should lead us to downplay the importance of personalities.

\section{RACE AND RACISM}

There is another element to the present story that is somewhat disturbing, and that is the issue of race and race matching. As is well known, it used to be common practice for adoption agencies to try to race match adoptive children with parents, but this is now far less common and I believe for good reason. The following questions which I asked some time ago still seems to me to be pertinent." "Why do so many people firmly believe that children should be like their parents, particularly in terms of their general colour and racial characteristics? It is difficult not to view this desire, and attempts to implement it, as a form of 'ethnic cleansing', it smacks very much of the pressure that so many societies and cultures have put upon their members not to 'marry out' or, to put it more bluntly, not to mate with somebody of another tribe or race. This has often taken the form of particular hostility to the resulting children, with pejorative terms like 'half caste' being used to describe the children of a mixed race union. As with prejudice against interracial marriage, the therapy of choice is surely not to prevent people from choosing their procreational partners according to their own preferences, but rather to try to eradicate the prejudice in society that makes people hostile to such unions and to the resulting children." This still seems to me to be the right approach to issues of race in reproduction and I believe that no weight should be given to the fact that we may see a white couple rearing black children or vice versa.

\section{THE AVOIDANCE OF BLUNDERS}

Murray and Kaebnick ${ }^{3}$ are, however, quite right that mistakes in assisted reproductive services are worrying and will undermine confidence in the whole process. I have a right to expect high standards of competence and professionalism when seeking assisted reproductive services and I am entitled to expect that my sperm and my partner's eggs or our embryos will not be mixed up or damaged or disposed of in ways of which we do not approve. Therefore while maintaining and insisting upon the high standards from assisted reproductive services where, as is inevitable in all human affairs, errors occur we should not, I think, give priority to the correction of those errors which may, from the point of view of both ethics and justice, be undesirable or unworkable but rather address directly the question of what is best for everyone in the circumstances which obtain.

In conclusion, the mix up, while disturbing, is not disastrous. We have one set of happy parents and hopefully a set of happy children. The man whose sperm was inadvertently misplaced should be free from parental responsibilities and not be entitled to parental rights in connection with the resulting children, but he should be compensated by the clinic involved and he and his partner given extra assistance in achieving the family that they desire.

J Med Ethics 2003;29:205-206

\section{Author's affiliation}

John Harris, Institute of Medicine, Law and Bioethics, School of Law, University of Manchester, Manchester M13 9PL, UK; John.M.Harris@man.ac.uk

\section{REFERENCES AND NOTES}

1 Spriggs M. IVF mixup: white couple have black babies. J Med Ethics 2003;29:65

2 Fuscalde G. What makes a parent? It's not black or white. J Med Ethics 2003;29:66-7. 3 Murray TH, Kaebnick GE. Genetic ties and genetic mixups. J Med Ethics 2003;29:68-9.

4 Harris J. The value of life. London: Routledge \& Kegan Paul, 1985: ch 7.

5 Harris J. Is gene therapy a form of eugenics? Bioethics 1993;7:178-87

6 A figure of $10 \%$ is often cited. See Emery $\mathrm{EAH}$. Elements of medical genetics [6th ed]. Edinburgh: Churchill Livingstone, 1983. The highest percentage of non-paternity I have seen cited is $30 \%$ by Dr Elliot Philipp. (See Wolstenholme GEW, Fitzsimmons DW, eds. Law and ethics of AID and embryo transfer. Amsterdam: Associated Scientific Publishers, 1973. Doubt has been cast on the credibility of the highest figures, although high figures have been confirmed to me anecdotally. See Maclntyre S, Sooman A. Non-paternity and prenatal genetic screening. Lancet 1991;338:869-71

7 Harris J. Rights and reproductive choice. In: Harris J, Holm S, eds. The future of human reproduction. Oxford: Oxford University Press, 1998:5-38. 


\section{Therapeutic cloning research and ethical oversight}

\section{Spriggs}

\section{There should be government funding for therapeutic cloning research-and do we really need a moratorium on such research?}

W ith access to Advanced Cell Technology (ACT), a biotechnology company doing therapeutic cloning, science writer and former biotech researcher Kyla Dunn followed the case of Trevor Ross, a two year old boy with a devastating genetic disease, and Advanced Cell Technology's experimental work and efforts to help him. The appeal of the story is that it gives a human face to the people whom therapeutic cloning could benefit. The story is true but the names of Trevor and his family have been changed. ${ }^{1}$

Advanced Cell Technology (ACT) is a privately owned company and the only group in the US "openly pursing human therapeutic cloning research". After approaching the company, Dunn wrote:

I wanted to know what motivated ACT's scientists. I wanted to observe firsthand what was happening in their cloning lab. I wanted to meet ordinary people afflicted with illness for which therapeutic cloning represented a potential cure. And, perhaps most important, I wanted to understand what happens to scientific progress when the burdens of research and development in an ethically sensitive area like cloning fall on the private sector rather than on the government. $^{2}$

Trevor Ross and two of his cousins have X-linked adrenoleukodystrophy (ALD) a devastating, often fatal condition. Trevor's cousin Andrew was the first affected. Andrew was described as a bright boy who loved baseball, played the violin, and apart from being "given a diagnosis of attention deficit hyperactivity disorder"when he started kindergarten, seemed to be thriving. ${ }^{3}$ But Andrew began having cognitive problems and by the time he was 8 years old he suffered a dramatic and progressive loss of coordination and it was clear there was something terribly wrong. With "alarming swiftness" after his ALD was diagnosed, he went blind and deaf, lost motor and bowel control and was unable to speak or move. This occurred by the time Andrew was nine. ${ }^{3}$

Both Trevor and Andrew's seven year old brothers also have the gene for ALD. Childhood cerebral onset of ALD affects mainly boys and half of those who

\section{Abstract}

Cloning Trevor, a story about therapeutic cloning research, appeared in the June issue of The Atlantic Monthly. The story gives a human face to the people whom therapeutic cloning could benefit. It presents an argument for government funding and it puts the usual calls for a moratorium on embryonic stem cell research to allow for more debate, in a less favourable light. The story also highlights some problems with ethical oversight.

develop childhood cerebral onset are dead by the time they are nine. Current treatment for ALD is a bone marrow or umbilical cord blood transplant but compatible donors are extremely hard to find and the transplants do not always take. A quarter of the boys who receive a bone marrow transplant "die from complications related to the procedure". ${ }^{3}$

Treatment could not help Andrew because his condition had deteriorated too far. There was, however, still hope for Trevor. Trevor was less than a year old when he was diagnosed and he had not yet shown any signs of brain deterioration. Neurological symptoms of ALD rarely develop in children under the age of three and many develop normally until the age of seven. It seemed that Trevor might have a while before the need for conventional but risky treatment so Trevor's parents sought out ACT in the hope that an experimental treatment using human embryonic stem cells could be developed to create a transplant that Trevor's body would not reject. ${ }^{3}$

In Cloning Trevor, Dunn writes about the ACT scientists' efforts to try to create cloned embryos with Trevor's skin cells. She describes the ordeal of getting two mature eggs and the painstaking work of trying to fuse the empty eggs with Trevor's skin cells. First of all, the eggs have to be donated and retrieved from young women. Then the scientist has to remove the chromosomes from the eggs by carefully piercing the egg's outer membrane and by applying suction to remove the cytoplasm. A skin cell is drawn into a needle and inserted into the egg and a pulse of electricity is used with the hope of fusing and activating the egg. ${ }^{4}$

Unfortunately both eggs lost their outer membranes and became unusable: the months of hoping and waiting came to nothing. ${ }^{4}$ In a "last ditch effort to save the eggs", after conferring briefly, the team tried to transfer the human eggs into empty cow eggs from the cow cloning lab-but that also failed. ${ }^{5}$

For Trevor, all hope of developing an experimental cure was finally dashed, when in February 2002 signs of childhood cerebral onset of ALD were detected. ${ }^{6}$ In April, after ten days of chemotherapy, Trevor had a conventional umbilical cord blood stem cell transplant. ${ }^{7}$

In Cloning Trevor, Dunn concludes that "real progress" in therapeutic cloning requires government funding and support. While there is a ban on federal funding the companies doing therapeutic cloning research will be private companies like ACT “which, despite generally noble intentions, are bedevilled by the need to raise money, generate buzz, and please investors". ${ }^{6}$ The "importance of federal funding cannot be overstated" Dunn argues. Government funding "attracts talented researchers at universities and research institutes" and with that "comes ethical oversight and peer review, ensuring that experiments are well designed, conducted by qualified scientists, and targeted at pressing questions in the field". ${ }^{7}$ Dunn makes no overt criticisms of ACT but neither does she shirk from reporting aspects of their research that are likely to attract criticism.

Some people see ACT's experimental work in a less favourable light than Dunn. The company generated considerable criticism and controversy in November 2001 when it announced prematurely that it had the world's first cloned human embryos. ACT was accused of harming the progress of therapeutic cloning research. According to an editorial in The New York Times, "by rushing into print with such preliminary results, and orchestrating a media blitz to accompany the announcement, Advanced Cell Technology has invited legislative retaliation that could cripple the very research it is attempting to pioneer". The 
company's motives have also been questioned: "Biotechnology companies are dependent on investors, and investors like publicity". ${ }^{8}$

Another controversy in which ACT is embroiled relates to the suspicion and mistrust generated by companies having their own private ethics advisory boards. Although private companies such as ACT are not required to have ethics advisory boards, ACT does have one. It has been called "window dressing for a corporate marketing plan". . Nevertheless, the reasoning of ACT's board shows that this particular advisory board is not "window dressing" in the sense that it exists only to legitimise the company's research. It could be argued, however, that the board's idiosyncratic reasoning does not amount to ethical review-rather, it shows how muddled reasoning can impede beneficial research.

One of the "leading ACT scientists" is said to have asked its ethics advisory board if there was any type of person who should be ruled out as a tissue donor for nuclear transfer research: "What about a child" he asked. Federal regulations permit research involving children as long as it provides knowledge that is likely to be of "vital importance" in understanding or ameliorating that child's disorder, and non-therapeutic research is allowed as long as the research is only "a minor increase over minimal risk". ${ }^{10}$ At first the board was unable to come up with any class of donor that was unacceptable, but in relation to the question of children as donors most felt a "hunch" that "there was something disturbing about this possibility". Then, "on reflection" the board "quickly and unanimously concluded" that a cell line derived from a child "could not be used in therapeutic cloning research":
Imagine that twenty years from now, when the child has grown up, she becomes an ardent "right to life" proponent. She firmly believes that life begins at conception or as soon as there is a self replicating genome. She learns that when she was very young, her parents took a skin cell from her that was used to create a cloned embryo. This embryo was later destroyed for research purposes. The young adult now feels that, without her knowledge or consent, she was made party to morally offensive acts. ${ }^{10}$

On this reasoning, if the procedure had been perfected, Trevor could not be helped because of a wrong that might be done to him if "years from now" he comes to hold a rigid minority view about the sanctity of life that interprets the attempt to save him as a "morally offensive" act. No consideration is given to the likelihood or gravity of harms and benefits. ${ }^{11}$

A report by the US President's Council on Bioethics was released on 11 July 2002. It recommends that cloning for biomedical research be prohibited during a four year moratorium. ${ }^{12}$ Patient advocates and scientists view the moratorium "as tantamount to a ban". They claim that the council was "stacked from the beginning" with those who oppose cloning research and that the outcome might have been different if the panel had included an advocate for patients. ${ }^{13}$ It is unclear how the report's recommendations will affect therapeutic cloning research in the private sector. ${ }^{14}$

J Med Ethics 2003;29:207-208

\section{Author's affiliation}

M Spriggs, Ethics Unit, Murdoch Children's Research Institute, Royal Children's Hospital, University of Melborne, Flemington Road, Parkville, Victoria, 3052, Australia;

spriggsm@murdoch.rch.unimelb.edu.au Also: Centre for Human Bioethics, Monash University

\section{REFERENCES AND NOTES}

1 Dunn K. Cloning Trevor. Atl Mon 2002:289:31-52, www theatlantic. com and follow links to Dunn (accessed 15 July 2002).

2 See reference 1: 33

3 See reference 1:36.

4 See reference 1: 46-50.

5 See reference 1: 50-1.

6 See reference 1: 52

7 Interview. The life (and death?) of cloning Atlantic Unbound (The Atlantic Monthly's online journal) 2002 May 22. Kyla Dunn, the author of The Atlantic Monthly's June cover story, talks about the state of therapeutic cloning research and why it should not be banned. at www.theatlantic.com/unbound and follow the links to inteviews (accessed 15 July 2002)

8 See reference 1: 43

9 Green R, DeVries K, Bernstein J, et al. Overseeing research on therapeutic cloning: a private ethics board responds to its critics. Hastings Cent Rep 2002;32:27-33. This is an article written by the ACT ethics board.

10 See reference 9: 31

11 See reference 9 . This article written by the ACT ethics advisory board appeared in the May/June issue of the Hastings Center Report. It is a response to its critics and to the criticism that a private ethics board's advice can go unheeded. The board refers to the consent forms for the donors of somatic cell tissue as an example of one incident in which researchers ended up implementing the board's recommendations even though the recommendations impeded or slowed research. The article describes the ACT scientist as "crestfallen" when he heard the board's conclusion. It is not clear when this article was actually written and it contains no reference to the work done with Trevor's skin cells but it seems that ACT did disregard its ethics advisory board in this matter.

12 The President's Council on Bioethics. Human cloning and human dignity: an ethical inquiry [prepublication version]. Washington, DC: The President's Council on Bioethics, 2002 Jul. www. bioethics.gov and follow links to Cloning Report (accessed 20 March 2003).

13 Stolberg S. Bush's bioethics advisory panel recommends a moratorium on cloning research. The New York Times 2002 Jul 11

21 . www.nytimes.com and follow links to CLON (accessed 15 July 2002).

14 Weiss R. Bush panel has 2 views on embryonic cloning. Washington Post 2002 Ju

11:5. www. washingtonpost.com and follow links to Jul 11 .html (accessed 15 July 2002).

\section{Withholding artificial feeding from the severely demented: merciful or immoral? Contrasts between secular and Jewish perspectives}

J Kunin

According to Jewish law, to make a judgment that a life has no purpose and is not worth saving is contrary to the concept of justice

$\mathrm{T}$ raditional medical practice dictates that when patients are unable to eat or drink enough to sustain their basic nutritional requirements, artificial feeding and hydration is indicated. Common clinical examples of this problem are patients with senile dementia and those in a persistent vegetative state (PVS). In recent decades, however, the practice of mandating artificial feeding has been increasingly questioned. A combination of legal, ethical, and clinical considerations has resulted in broad support for withholding and withdrawing artificial nutri- tion. The guiding ethical principle in the current clinical standards is that patient autonomy must be honoured. In the context of an incompetent adult (such as a patient with advanced dementia or in a PVS), advance directives or surrogate decision making are legally binding. Such 
requests to withhold artificial nutrition are considered appropriate and even encouraged. ${ }^{1}$ Such a view, however, is not unanimous. For example, Catholic writers have questioned the current consensus. The New Jersey Catholic Conference has written that withholding nutrition and hydration from such patients "ultimately results in starvation, dehydration, and death," and that withdrawing such basic care from patients who are not dying but in a PVS "is a clear statement that the patient's life has no moral value". ${ }^{2}$ This question is also of great concern in Jewish law (halachah). In contrast to secular medical ethics, halachah requires that artificial feeding be given to patients with dementia or in a PVS. The following discussion gives an overview of the pertinent arguments that have led to the consensus in secular ethics that artificial feeding may be withheld from the severely demented and the halachic considerations that argue against this practice.

\section{CLINICAL ARGUMENTS IN FAVOUR OF WITHHOLDING ARTIFICIAL FEEDING}

The most obvious clinical objective in artificially feeding demented patients is to sustain their lives by preventing starvation. In recent years, however, some authors have argued that severe dementia is a terminal condition and that artificial nutrition does not extend life. As Gillick writes, "There is a pervasive failure to view advanced dementia as a terminal illness". She argues that eating and swallowing disorders in a demented patient are "independently associated with mortality". ${ }^{3}$ This declaration, however, is not supported by available data. In one study of demented patients who were totally dependent on others for eating, the one year survival rate was $80 \% .{ }^{4}$ In another study, Mitchell et al, reported that in demented patients with eating and swallowing disorders $86 \%$ were alive at one year. ${ }^{5}$ These statistics do not support the notion that demented patients with eating and swallowing disorders are terminally ill. Indeed, Meyers and Grodin write that severely demented patients "are neither terminal nor suffering from a painful condition". They continue: "Severe dementia is not predictive of eating dependency once abnormal oral motor behavior was considered. This suggests that the neurologic changes in swallowing that are seen in dementia may be variable in timing and presentation." Meyers and Grodin conclude: "Elderly patients with dementia are similar to persistent vegetative state (PVS) patients in that neither group are terminal. Both these groups can be expected to live years if tube feeds are supplied."

It has been argued $^{37}$ that there is no evidence that tube feeding prolongs life.
This unexpected conclusion is based largely on two retrospective studies. In a 1997 report by Mitchell et al, ${ }^{4}$ patients were studied who were totally dependent on others for eating. Patients who were tube fed and those who were hand fed had similar one year survival rates of $80 \%$. Their conclusion was that "tube feedings did not affect survival in this frail population". A serious weakness of this study was that they specifically excluded those who were in the most severe category of dementia (the patients who were unable to eat by mouth, even by spoon feeding). In other words, the investigators excluded those most likely to benefit from tube feeds and most likely to die from starvation if not artificially fed. In another widely quoted paper ${ }^{5}$ a large population of demented patient with eating and swallowing disorders was studied. The results showed that those patients without tube feeds had an $86 \%$ one year survival rate and that those patients who were tube fed actually had a $10 \%$ higher mortality rate. This study is cited by some authors to support the conclusion that there is no proof that artificial feeding prolongs life. This study suffers from being retrospective and cannot control for confounding factors that may make the two study groups not comparable. Moreover, the $86 \%$ one year survival rate in those who did not receive tube feedings implies that these patients, in fact, were able to eat despite their swallowing disorders and were likely not to have been comparable to the patients requiring tube feedings. In summary, no conclusion can be drawn from these studies regarding the effect of tube feedings on longevity. The cited studies do not address the group of patients that cannot eat by mouth, even by spoon feeding, and would starve if it were not for artificial feeding.

In fact, there is widespread acknowledgment that withholding nutrition shortens life. A consensus statement of the American Academy of Neurology asserts that "withholding life-sustaining therapy may shorten life". ${ }^{8}$ Peck et al, write that "the terminal phase of dementia may be prolonged for months or even years" if supportive care such as artificial nutrition is administered. ${ }^{9}$

It has been argued that PEG (percutaneous endoscopic gastrostomy) tubes cause suffering manifested by high complication rates, that they require restraints, and that they lead to a more uncomfortable death. In a review of the literature, Larson et al, found that in 314 PEG placements, three deaths were attributable to the procedure itself-one from laryngospasm and two from aspiration. ${ }^{8}$ While any operative mortality is of great concern, a $1 \%$ mortality for a procedure that may indefinitely prolong life is halachically considered an acceptable risk (Rabbi Yaakov Weiner, written communication, 2002). One can think of palliative surgical procedures such as gastric and biliary bypasses in terminal cancer patients that are associated with higher operative mortality and a lower long term survival but which are well accepted medical procedures. Moreover, the high 30 day complication rates in all series of PEG placements are overwhelmingly related to the patient's underlying medical conditions and not to the PEG placement itself. The most commonly cited PEG related complications are infections (which were reduced from 30\% to 7\% with the use of prophylactic antibiotics) and tube displacement. ${ }^{10}$ This latter complication is minor and only requires replacement of the gastrostomy tube-a very simple, painless procedure.

A widely quoted concern is that tube feedings result in greater use of restraints, and that this, in turn, adds mental suffering to these fragile patients. The source for this assertion is a report from Peck et al. ${ }^{11}$ A careful reading of this report demonstrates, however, that there was no statistically significant difference in use of restraints between tube fed and non-tube fed patients. Moreover, $78 \%$ of those patients who were given artificial nutrition were fed by nasogastric (NG) tube. The PEG technique is a technological advance that makes artificial feeding more comfortable for patients. One would expect restraints would be less necessary with PEG tubes than with NG tubes.

In conclusion, the available literature demonstrates that severe dementia is not a terminal disease, that there is no data to argue against the assumption that artificial nutrition will prolong life in patients who are unable to eat orally, that complications rates are not excessive with PEG tubes, and that there is no added suffering from tube feedings.

\section{ETHICAL ARGUMENTS}

The argument that withholding tube feedings in demented patients is permissible is based on the idea that withholding medical technology and allowing nature to take its course is morally acceptable. The assumption is that these patients can be kept alive, but there is nothing wrong with allowing them to die by starvation, particularly when advance directives have been established.

Court decisions have led the way in not mandating tube feedings in PVS and demented patients. The principle of autonomy weighs heavily in these legal decisions. As Steinbrook and Lo have stated: "[The] right to refuse artificial feeding outweigh[ed all the state's] interests". ${ }^{12}$ One court summed up this principle by writing: "The right to refuse medical therapy is virtually absolute and patient motives were not a matter of debate". The Council of Ethics of the AMA has stated: "It is not unethical to 
discontinue life prolonging therapy in patients with PVS". ${ }^{13}$ In such circumstances (severe dementia being similar), the council argues, artificial feeding is extraordinary care and similar to cardiopulmonary resuscitation (CPR) and mechanical ventilation. It is important to emphasise that no distinction is made in these statements between terminal and non-terminal disease. In Jewish law the distinction is important. The question of whether to initiate endotracheal intubation and mechanical ventilation in a terminally ill cancer patient and whether to insert a PEG tube in a demented patient without any terminal illness are not considered comparable cases.

All ethical arguments in favour of withholding nutrition assume that demented patients are qualitatively different from other patients. Lo and Dornbrand argue that severe dementia is the end of a progressive downhill course and "stopping to eat is a natural letting go of life $\mathrm{e}^{\prime{ }^{14}}$ Hanson et al, emphasise the concept of medical futility. They declare that when a favorable outcome "offers the opportunity to achieve life goals" it is not futile. Their conclusion is that such states as PVS and dementia exclude the possibility of achieving "life goals" and so any intervention to lengthen the lives of such patients is by definition futile. ${ }^{15}$ The core of their argument is that these patients are not sentient beings, and merit less care. So, too, Rabenick et al, have stated:

If the intervention is only expected to improve the patient's physiological effects, but does not have any effect on quality of life such as in a patient with PVS, then the physician should recommend against such interventions. The minimal function of PVS patients eliminates the possibility of experiences and activities that make human life valuable-that is, they cannot experience quality of life. Medical interventions that only sustain minimal function do not benefit the patient overall. ${ }^{16}$

While autonomy has great legal weight, several authors argue that the case against nourishing such patients is so strong that it should override the principle of autonomy. Gillick has stated: "If family members are unable to make a decision, the physician should assume that a person with advanced dementia would not want a feeding tube". ${ }^{3}$ Schneiderman et al, write:

We believe that qualitatively poor results fall outside the range of patient autonomy and need not be offered as options. The clearest of these qualitatively poor results is continued biologic life without conscious autonomy. The patient has no right to be sustained in a state in which he has no purpose other than mere vegetative survival. ${ }^{17}$

\section{THE HALACHIC APPROACH}

The current standard that allows for the withholding and withdrawing of artificial nutrition is not universally accepted. Rosin and Sonneblick, geriatricians reporting from a Jerusalem hospital that is guided by halachic principles, state that in their practice artificial feeding is given to patients with senile dementia and is considered proper, moral care. ${ }^{18}$ In an article surveying general attitudes among health care providers towards artificially feeding demented patients, Israelis were more in favour of force feeding than a similar survey in Sweden. The authors concluded that the Israeli attitude was based on the Jewish tradition that gives a very high priority to preservation of life. ${ }^{19}$

A halachic ruling on the advisability of placing a PEG tube in a severely demented patient depends on several practical considerations. These include the prognosis of the disease, the physical and mental suffering the patient must withstand, and the efficacy of the PEG tube in achieving its goal of prolonging life. What is specifically not a consideration in the calculus is the perceived quality of life of the patient.

Rabbi Yaakov Kanevsky, a leading rabbinic figure of the 20th century, has written $^{20}$ that the first halachic principle of medical intervention is that whenever it is possible to increase the longevity of a patient, it should be done. A cardinal principle of Judaism is that every moment of life is considered precious and of infinite worth. He continues by warning that while there are exceptions to this general rule, they must be applied with great caution and only on a case by case basis. In other words, the halachic premise is always in favour of treating and promoting life. The exceptions to this rule usually involve persons known to be terminally ill and who are suffering. Both of these conditions must be met. Neither alone is sufficient to withhold treatment. Terminal illness in halachic terms means there is a near certainty that the patient will die soon. The exact time frame is a subject of dispute. The most influential living halachic authority, Rabbi Yosef Shalom Elyashiv has stated this to be a life expectancy of no greater than three months (Rabbi Yaakov Weiner, written communication, 2002). It is important to underscore that in rendering a halachic decision, the definition of terminal illness is not related to its natural history, but includes the prognosis, taking into account all the resources of modern medicine. A natural history of a disease independent of currently existing treatment is of no interest to the halachic judge. That a severely demented patient who cannot eat will "naturally" die from lack of nutrition in a "natural letting go of life," is an artificial construct, which ignores the reality that artificial feeding will allow him to live on indefinitely.

When a person is determined by medical opinion to be terminally ill despite all medical treatment and he is suffering, initiating new treatment is not required if it only minimally increases life expectancy. Rabbi Moshe Feinstein, one of the great halachic authorities of the last half century, has written that added suffering outweighs the small benefit of a minimally increased life expectancy, and the treatment should not be given. ${ }^{21}$ Given the data as outlined above, however, the severely demented patient who does not eat cannot qualify for this important exception to the general principle that life must be supported and promoted. As mentioned earlier, there is no medical evidence that such patients are terminally ill. To the contrary, most authorities specifically state that the severely demented are, in fact, not terminal and are not suffering from a painful condition.

Regarding the efficacy of tube feeds, the halachic judge must weigh the complications versus the benefits of the procedure. The benefits, while not well quantitated clinically, are simply to prevent starvation in a patient who is unable to eat. In other words, there is a presumption that feeding a patient who is getting insufficient nutrition will certainly increase their life expectancy and convert them from what would be a terminal state of starvation to a life that is now indefinitely prolonged. Rabbi Feinstein specifically stated: "When a patient is currently terminal, but can be given medicine to make them nonterminal and live indefinitely, the therapy is required". ${ }^{22}$ Moreover, in analysing the risk benefit analysis of tube feeds, the complication and mortality rates of PEG tubes are very low considering the likelihood that artificial nutrition will increase the patient's longevity.

It is important to note that Rabbi Feinstein adds that physical coercion should not be used to force patients to accept therapy. He limits his discussion to the competent adult. One may extrapolate from his concern about coercion that if a severely demented patient refuses tube feedings by repeatedly pulling out tubes, physical restraint is a most undesirable solution. No generalisations, however, can be offered here, and, as always in Jewish law, such problematic cases can only be judged by individual rulings. It would appear, though, that such a refusal in an incompetent patient does not necessarily mandate cessation of artificial nutrition. Such a situation may require adjustment of medications 
to control agitation or depression. It is clear, however, that physical restraints should be avoided.

For advocates of withholding artificial nutrition the outstanding question is the value of the life of a severely demented patient. This concept is sharply opposed by halachic authorities. Professor Abraham B Abraham, a pupil of the great halachic authority, Rabbi Shlomo Zalman Auerbach, writes:

Every portion of a life of a man has infinite worth -70 years of a man has exactly the same value as 30 years, as one year or one hour. The infinite value placed on human life [means] that if the value of the end of the life of a man is reduced, the absolute value of his life has been lost and one has made the value of his life relative-relative to his usefulness, the condition of his health, his benefit to fellow human beings, or by any other measure. Then, there will be a need to grade men and two men are never equal in their value. The moment that the life of a man becomes defective and he may soon die, his value deteriorates .... There is no limit to what becomes possible in limiting the value of men. ${ }^{23}$

The Jewish argument, though, is not just out of concern for the slippery slope. Judging any human life as more or less valuable is categorically rejected. As Rabbi Auerbach writes:

Even though it is clear that [such a] life is not life as we understand life to be, and it is extremely difficult for both the patient and family to withstand such suffering, we are none the less commanded to make every effort to preserve and save his life .... We are commanded [to save the life of] a sick old man, a deaf mute, one completely retarded and incapable of performing [any useful function]. Even in such circumstances it is of great [merit] to make every effort to pursue saving his life. ${ }^{24}$

Rabbi Feinstein also addresses the issue of quality of life explicitly:

There is no place to consider quality of life. Considering a retarded person or one in a vegetative state there is no place to think there is not the same mandate to treat such patients. When there is no suffering and they are able to live a long time it is clear and simple that they require the same care as anyone and no regard is paid to their sentience. ${ }^{21}$

In measuring a man's life by its quality or considering it worthwhile only when he is able to pursue certain goals, ethicists are making sweeping judgments. If ethicists, judges, physicians, or family members have the authority to determine which life is worth living, they are able to decide which life is worth saving and which is not. This is extraordinary power. To make the moral dilemma more difficult, there may be unconscious bias in allowing the severely demented to die from starvation. Rango has stated:

As a group, the impaired elderly are a potent source of disagreeable and even hateful mental images capable of generating fear, anger, and guilt in the minds of those who are chronically exposed to the ravages of geriatric disease .... . Why do these shadows of former selves refuse to die? Why do these vacant minds and misshapen bodies incapable of living alone continue to burden the lives of others? By appearance and behavior, the demented elderly sorely challenge one's sense of compassion and benevolence. Senility itself poses a terrible psychic threat reminding one of the dark human potential to lose personal identity, awareness, and self control in old age. An insidious mental process can thus unfold if one begins to project these feelings of personal anguish to the demented person who is then regarded as having a diminished quality of life. This form of psychological projection can lead to a willingness to end the demented person's life for his own good even though observable evidence of great pain and distress is lacking. ${ }^{25}$

One exception to the judicial trend to allow a severely demented patient to die was the New Jersey Supreme Court rejection of a request to remove the feeding tube in the case of Conroy. In their summary they stated that it was not proper to terminate care on "assessments of the personal worth or social utility of another's life or the value of that life to others" ${ }^{26}$ Thus there is a concern that the manner in which "policy choices and clinical decisions are now being framed cuts against the best interests of the disabled, the sick, and the dying". Rango concludes: "Recognising their mental incapacity, we ought to devise stringent ethical standards that protect persons with dementing illnesses from discrimination in its various forms". Patients with severe dementia as well as with PVS are arguably the most vulnerable members of society, with few advocates, and no political power.

It has become increasingly acceptable today to judge the life of some of our fellow human beings, such as those with severe dementia and PVS, as less worthy of preserving. Rabbi Shlomo Zalman Auerbach, who typified the ideal rabbinic personality of unparalleled intellectual power and scholarship, combined with renowned humility, wrote: "We have no ability to determine the preciousness and the importance of any life, even when that person is incapable of [performing any useful function]". ${ }^{24}$ To think otherwise, to presume that we have the authority to decide who we will sustain and who we will allow to die, is a kind of arrogance that is an anathema to the benevolent human society that is at the core of what Jewish law and ethics promotes.

\section{ACKNOWLEDGMENT}

I am grateful to Rabbi Yaakov Weiner of the Jerusalem Center for Research in Medicine and Halachah who reviewed the manuscript. It is with his counsel that I have attempted to present the accepted halachic consensus on this subject. Any error or misrepresentation in this regard is, however, because of my own misunderstanding.

\section{J Med Ethics 2003;0:208-212}

\section{Author's affiliation}

J Kunin, PO Box 487, Zichron Yaakov 30900, Israel; jkunin@netvision.net.il

\section{REFERENCES}

1 American Medical Association. Decisions near the end of life. JAMA 1992;267: 2229-33.

2 New Jersey Catholic Conference. Providing food and fluids to severely brain damaged patients. Origins 1987; 16:582-4.

3 Gillick MR. Rethinking the role of tube feeding in patients with advanced dementia. N Engl J Med 2000;342:206-10.

4 Mitchell SL, Kiely DK, Lipsitz LA. The risk factors and impact on survival of feeding tube placement in nursing home residents with severe cognitive impairment. Arch Intern Med 1997; 157:327-32.

5 Mitchell SL, Kiely DK, Lipsitz, LA. Does artificial enteral nutrition prolong the survival of institutionalized elders with chewing and swallowing problems? J Gerontology 1998;53A:M207-M13.

6 Meyers, RM, Grodin MA. Decision making regarding the initiation of tube feedings in the severely demented elderly: a review. JAGS 1991:39.526-31.

7 Finucane TE, Christmas C, Travis, K. Tube feeding in patients with advance dementia. JAMA 1999;282: 1365-70.

8 The American Academy of Neurology Ethics and Humanities subcomittee. Ethical issues in the management of the demented patient. Neurology 1996;46:1180-3.

9 Peck A, Cohen CE, Mulvihill MN. Long term enteral feeding of aged demented nursing home patients. JAGS 1990;38:1 195-8.

10 Larson DE, Burton DD, Schroeder KW, et al. Percutaneous endoscopic gastrostomy. Gastroenterology 1987;93:48-52.

11 Taylor CA, Larson DE, Ballard DJ, et al. Predictors of outcome after percutaneous endoscopic gastrostomy: a community based study. Mayo Clin Proc 1992;67: 1042-9.

12 Steinbrook R, Lo B. Artificial feeding-solid ground, not a slippery slope. N Engl J Med 1988;318:286-90.

13 American Medical Association. Current Opinions of the Council of Ethical and Judicial Affairs of the American Medical Association-1986. Withholding or withdrawing life prolonging medical 
treatment Chicago: American Medical Association, 1986

14 Lo B, Dornbrand L. Guiding the hand that feeds. N Engl J Med 1984;31 1:402-04.

15 Hanson LC, Rodgman E. The use of living wills at the end of life. Arch Intern Med 1996;156:1018-22.

16 Rabeneck L, McCullough LB, Wray NP. Ethically justified, clinically comprehensive guidelines for percutaneous gastrostomy tube placement. Lancet 1997;349:496-8.

17 Schneiderman LJ, Jecker NS, Jonsen AR Medical futility: its meaning and ethical implications. Ann Intern Med 1990;112: 949-54.

18 Rosin AJ, Sonnenblick M. Autonomy and paternalism in geriatric medicine. J Med Ethics 1998;24:44-8.

19 Norberg A, Hirschfeld M. Feeding of severely demented patients in institutions: interviews with caregivers in Israel. J Adv Nurs 1987; 12:551-7.

20 Kanevsky, Rabbi Y. If one may remove the mandate to lengthen the life of a patient. Krinna D'Agrata 1980;190:201.
21 Feinstein $M$. On the matter of treating patients who are incurable. Igrot Moshe,
Choshen Mishpat II, 1984: section 84.1. Choshen Mishpat II, 1984: section 82
See reference 21: section 84.3.

22 See reference 21: section 84.3 .
23 Abraham AB. The laws of visiting the sick. Nishmat Avraham, Yoreh De'ah, 339.4.

24 Auerbach SZ. On treating a dying patient. Minchat Shlomo 1986;91:24.

25 Rango N. The nursing home resident with dementia. Ann Intern Med 1985;102:83541

26 New Jersey Supreme Court. In the matter of Claire C Conroy. Docket no A-108, January 17, 1985

\section{MRSA in the Netherlands: preventive measure raises a moral issue}

$T^{s}$ he problems caused by MRSA (methicillin resistant Staphylococcus aureus) infections have recently been discussed in three Dutch daily newspapers. On May 24, 2002 an article appeared in the Algemeen Dagblad with the startling title: The lost battle against MRSA. ${ }^{1}$ It describes how Dutch hospitals are trying to prevent the spread of the antibiotic resistant forms of Staphylococcus aureus, which can be life threatening to patients with a reduced resistance towards bacterial infections. So far, the frequency of MRSA in Dutch hospitals has been relatively low in comparison to the incidence in other countries. This favourable situation has been ascribed to the manner of isolating patients with MRSA and to the restrictive use of antibiotics by Dutch general practitioners. At a time when hospitals are understaffed, it is clear that the labour intensive care of patients with MRSA can become a serious problem. In general, Dutch hospitals are reluctant to accept patients who wish to be repatriated after being treated in a hospital outside the Netherlands. In fact, the minister of health has been asked to finance the building of a special hospital where these patients can be kept in quarantine. This would, however, have the drawback that general hospitals would lose their expertise in treating patients with MRSA.

Another article on MRSA appeared on June 23, 2002 in the NRC Handelsblad and had as its title: Operation dirty hands. The medical staff is often the cause of MRSA outbreaks. ${ }^{2}$ It is a report of a lecture by a bacteriologist, E Mascini, who found that a quarter of the MRSA outbreaks could have been prevented, if medical staff had followed painstakingly the existing directions on taking care of

\section{Abstract}

In the Netherlands the incidence of methicillin resistant Staphylococcus aureus (MRSA) infections in hospitals is surprisingly low when compared to that of neighbouring countries. It is believed that this favourable condition is caused by stringent precautionary measures such as complete isolation of the patients. In one case the nurse taking care of such patients was herself MRSA positive. This condition changed and she became MRSA negative after removal (at her request) of her tonsils. The question is raised how far one should go to protect patients when the preventive measures taken may endanger the health of those who take care of them.

patients with MRSA. Furthermore, 50\% of the staff working with these patients also became infected with MRSA. The bacteriologist is of the opinion that patients with MRSA, who are returning from a foreign hospital, should be kept in complete isolation until tests show they are no longer MRSA positive. This raises the question whether travel agencies should warn their clients of the problems they may encounter, if they wish to enter a Dutch hospital as a patient after returning from (a hospital in) another country.

A further source of MRSA infection are the Dutch nurses or doctors who have worked abroad. On returning home they may not have informed their employer where they have worked and this may have catastrophic consequences, if they should have become carriers of MRSA.

A third article on MRSA appeared in the newspaper Trouw, on June 28, 2002. It describes the interesting case of a nurse, working in a hospital in Den Bosch, who remained MRSA positive, even after treatment with various antibiotics. Here follows a translation of a statement by the bacteriologist, A Leenders, contained in that article: "One of the nurses, on her own initiative, suggested to the specialist that she should have her tonsils removed, because it was suspected that the MRSA resided in this organ. At the time it was uncertain whether the operation would change the MRSA status of the nurse. After the tonsillectomy, tests showed that the health worker had become MRSA negative. This indicates how far people will go. They have chosen to work in health care and they do not allow a bacterium to interfere with their vocation". I find this an altruistic attitude, but it does raise the moral question whether health care workers should undergo medical treatment with its inherent risks of complications, for the sake of the patients in their care?

J Med Ethics 2003;29:212

......

s affiliations

D O E Gebhardt, Anna van Burenlaan I, 2341 VE Oegstgeest, the Netherlands; doe.gebhardt@planet.nl

\section{REFERENCES}

1 Veen $\mathbf{P}$. The lost battle against MRSA. Algemeen Dagblad 2002 May 24: 33

2 Vermij $\mathbf{P}$. Operation dirty hands. The medical staff is often the cause of MRSA outbreaks. NRC Handelsblad 2002 Jun 23: 41

3 Becker S. Insurmountable but controllable. Trouw 2002 Jun 28: 11. 